Part 4.

Studia Iuridica Lublinensia vol. XXVII, 1, 2018

DOI: 10.17951/sil.2018.27.1.167

\title{
Giovanni Pesce
}

Administrative Lawyer, Rome, Italy

giovanni.pesce@studiobdl.it

\section{Does the Plenary Session of the Italian State Council Become a Common Law Judge?}

\author{
Czy Zgromadzenie Plenarne włoskiej Rady Stanu staje się sędzią \\ common law? \\ SUMMARY
}

The article embraces the question of competence of the Italian Council of State (Consiglio di Stato) in the light of orders referred to in Article 99 of the Italian Administrative Procedure Code. The Council of State is a consultative legal-administrative organ, which guarantees the legality of the public administration. It is considered a bastion of the rule of law. Therefore, the author asks questions regarding the transformation of the system of justice in administrative cases towards common law. Conclusion: the administrative jurisdiction applies its competences for the benefit and protection of a citizen. Based on Article 99 of the Administrative Procedure Code, the mechanism consisting in applying the precedential practice imposes the forms of institutional cooperation in the administrative jurisdiction system. The author claims that a binding precedent is fully consistent with the principle of the rule of law and legality.

Keywords: Council of State; precedent; administrative proceedings

\section{INTRODUCTION}

Article 99 of the Italian Administrative Procedure Code approved by the legislative decree 104/2010 assigns a new role to the Plenary Session of the State Council. In particular, the third paragraph of Article 99 prescribes that if the section of the Council of State, which is assigned the appeal, believes that it does not share a "rule" laid down by the Plenary Session, transfer to the latter, by reasoned order, the decision of the appeal. It is a constraint that has different nature from the binding rule created by the decision that produces effects "between the parties" (such in the case of res iudicata); as well as it is different from the constraint to which the remand judge 
is subject to when applying the rule laid down by the Supreme Court of Cassation pursuant to Article 384 of the Civil Procedural Code. It is a role that goes far beyond the boundaries of the classic so-called nomofilactic function, whereby all apical jurisdiction shall ensure a uniform application of law although a binding de jure effect has been excluded (Article 45 of the old legislative statute No. 1054/1924).

Rather, the rule laid down by the Plenary Session resembles the rule of precedent typical of common law systems. Are we therefore faced with a transformation of administrative justice, traditionally considered the Italian bastion of the rule of law? Is the administrative process destined to become a process of common law?

If that were the case, Article 99 would introduce a novelty of undoubted importance. At a theoretical level, the skepticism against the creative role of the judiciary shall be subject to scrutiny. With regards to the Italian legal system, the consistency between Article 99 and some general principles of the rule of law shall be tested. With regards to the relationship between the citizen and the public administration, the positive impact of a binding precedent shall be assessed.

\section{THE DOCTRINE OF STARE DECISIS}

According to the doctrine of stare decisis, the elements defining a judicial precedent are the following:

a) a judicial decision, in addition to solving a given case, also represents an authoritative source of law to follow in subsequent cases that have some similarity ${ }^{1}$,

b) a court is bound to follow the decisions of higher courts and sometimes its own decisions ${ }^{2}$,

c) a decision is binding only as regards to its ratio decidendi,

d) an old precedent, although still valid, might not be applicable where significant changes have occurred,

e) the judge of the subsequent case analyzes critically the precedent and retains some freedom to interpret the ratio decidendi to such extent as to be able to decide the new case disregarding the precedent,

f) the technique of the overruling, designed to replace an old precedent, prevents that a unexpected change of the rule laid down in the precedent may undermine the expectations of those who have relied on the rule itself.

On a substantive level, the precedent is a means to create law. On a procedural level, the precedent is a special technique of dispute resolution.

${ }^{1}$ For the variations of the common law in the U.S. see: R. Pound, The deviation of American Law from English Law, "Law Quarterly Review" 1952, Vol. 67, pp. 44-46.

2 The Supreme Courts of the United States, unlike English courts, have not deemed to be bound by their own precedents. R. David, I grandi sistemi giuridici contemporanei (a cura di Sacco), Padova 1973, p. 373. 


\section{ARGUMENTS CONTRARY TO THE BINDING NATURE OF THE PRECEDENT (IN THE ADMINISTRATIVE PROCESS)}

In Italy, the doctrine of the precedent as a source of law has been subject to harsh criticism, both on formal grounds (the list of sources of law does not include judge-made law), on political grounds (based primarily on the principle of separation of powers), and on the argument that a judge creating law could invade and erode the powers where the sovereignty lies (once of the King, and today of the Parliament).

On the contrary, it seems unquestioned that the Constitution requires the judiciary to apply the law (Article $101 \S 2$ ) and not to create $i^{3}$. The common law assumptions are therefore rejected. The dogmatic construction of the system of the sources of law has been influenced by the $19^{\text {th }}$-century legal positivism, inspired by the myth of the self-sufficiency of the legislative power and hostile to the idea of the creative power of the judge.

However, as facts have proved over time, no ideology has been able to prevent that judges consciously created new law ${ }^{4}$.

\section{ARGUMENTS IN FAVOUR OF THE BINDING PRECEDENT (IN THE ADMINISTRATIVE PROCESS)}

\section{Theoretical arguments}

In the early 1900 s, scholars adhering to the legal realism acknowledge that law expresses itself also through judicial activity. Challenging the monopoly of statutory law, the merit of legal realists has been to innovate the legal debate especially with regards to the system of the sources of law5.

The impact of realists is undoubted. Not surprisingly, even our doctrine has subsequently shown to abandon the traditional scheme of $19^{\text {th }}$-century legal dogmatic. Such a claim is even stronger for the administrative judge, if we consider the massive and conscious creative work carried out by the Council of State throughout history.

${ }^{3}$ R. Guastini, Il giudice e la legge, Torino 1995.

${ }^{4}$ G. Tarello, Storia della cultura giuridica moderna, Bologna 1976.

${ }^{5}$ R. Pound, An Introduction to the Philosophy of Law, New Haven 1922; B.N. Cardozo, Selected Writings of Benjamin Cardozo (Il giudice e il diritto), New York, 1947 (trad. it. Firenze, La Nuova Italia 1961); A. Ross, On Law and Justice (Diritto e giustizia), Torino 1965; K. Olivecrona, La Law as Fact, London 1939; idem, Il diritto come fatto, Milano 1967. 
The administrative case law has been mainly carried out through a creative activity of the judiciary. Statutory law followed judicial decisions ${ }^{6}$. The techniques by which the administrative judge analyses the "excess of power" are by definition independent of any specific statutory rule and refer to general standards or principles (such as reasonableness, etc.), the application of which imply a broad discretionary power by the court ${ }^{7}$. By a clear rule of law, the administrative court shall ensure "full and effective protection" according to "the principles of European law" (Article 1 of the Italian Administrative Procedure Code) ${ }^{8}$.

In summary, if there is room - as it seems the case - for the civil court to "create" rules and fill in the gaps of the legislator or interpret the spirit over the letter of a statute, a far more significant room exists for the administrative court, because of the kind of actions it takes and of its power to ensure justice. The real novelty would consist in the binding effect of the precedent laid down by the Plenary Session on the individual sections. This aspect, however, would be a logical consequence of the above premises. A judge unstoppably creator of law, such as the administrative judge, can be bound by precedents of the Plenary Session.

\section{Political arguments}

The first argument typically mentioned in favour of the binding precedent is legal certainty ${ }^{9}$, a fundamental value that underpins any orderly community. In particular, the precedent is a tool to protect the expectations of citizens and as such a guarantee of greater liberty. The stare decisis, in fact, allows to predict in advance the behaviours sanctioned by law and plan your life choices accordingly. The ECHR has stressed the relevance of predictability ${ }^{10}$. Within the purposes of the European Convention on Human Rights, the notion of "law" is not linked to formal or procedural criteria. The European Court of Human Rights has developed, vis à vis all States, an "autonomous notion" of law, compatible with all European constitutional systems. Pursuant to the European Court, the univocity, consisten-

${ }^{6}$ See: S. Cassese, Problemi delle ideologie dei giudici, [in:] Studi in memoria di Carlo Esposito, Padova 1972, p. 1392 ff. Cfr. also M. Nigro, Giustizia amministrativa, Bologna 1983, p. 326 ff.

7 See: F. Patroni Griffi, La sentenza amministrativa, [in:] Trattato di diritto amministrativo, a cura di S. Cassese, tomo V, Milano 2003, p. 4468.

${ }^{8}$ Court of Justice of the European Union, October 6, 1982, causa C-283/81, Cilfit srl e Lanificio di Gavardo spa c. Ministero della Sanità, in Racc., 1982, 3415; adde Court of Justice of the European Union, September 15, 2005, causa C-495/03, Intermodal Transports BV c. Staatssecretaris van Financiën, Racc., 2005, I-8151.

${ }^{9}$ G. Lamond, Precedent and analogy in legal reasoning, [in:] Stanford Encyclopedia of Philosophy, 2006, http://plato.stanford.edu/archives/sum2006/entries/legal-reas-prec [access: 10.02.2018].

10 Sunday Times c. Regno Unito, decision April 29, 1979, §§ 48-49. As a consequence, the Court claims that the "law" is not knowable, and predictable, if the case law is contradictory and questioned (please note that the reasoning is the same for both common law systems and those of civil law). 
cy, intelligibility, and predictability of law are evidence of the effectiveness of the rule of law at a national level. Therefore, in the eyes of the Court, the "law" is not knowable or predictable if the law is often challenged and contradictory ${ }^{11}$.

Furthermore, predictability guarantees the liberty of citizens also in another way. The stare decisis sets forth stronger and more precise limits of the discretionary power of public officials, so that they may be held accountable where they have issued enactments in violations of the rules laid down in the precedents.

The stare decisis can be as well supported for reasons of efficiency. If courts are altogether consistent, rules are clearer and reasons for conflict decrease. The result is a deflation of litigation and processes.

The argument of predictability is intertwined with that of legal certainty. Therefore, if on the one hand the precedent seems to hinder the principle of the rule of law as it implies the recognition of a creative power of the judge, on the other hand, it serves to one of the functions that the principle of the rule of law aims at promoting, i.e., protecting citizens from arbitrary and unpredictable behaviour of the public authorities. Legal scholars have already stated that the rule of stare decisis is not only contrary to the principle of "rule of law", but it is actually its own corollary ${ }^{12}$.

\section{Logical-textual arguments}

On a strictly exegetic level, the very same formulation of the rule betrays the intention of the legislator to introduce into the legal system the binding precedent.

1. Article $99 \S 3$ of the code of the administrative process contains a prescriptive a not merely descriptive proposition ${ }^{13}$. The proposition "If the section does not share a rule of law laid down by the Plenary Session, transfer to the latter the decision by a reasoned order" means that "the section that doesn't share a rule of law cannot decide the case but must put it back to the Plenary Session by explaining the reasons for dissent". It cannot mean, however, that "the section that doesn't share the rule of law of the Plenary Session is free to depart from it, provided that it gives reasons". Where intended in this last way, the formulation would be superfluous.

${ }^{11}$ Explicit in this respect are the judgments that have defined the actions Kruslin c. Francia, April 24, $1990 \S \S 27-36$; Kopp c. Svizzera, March 25, 1998 § 73; Valenzuela Contreras c. Spagna, July 30, $1999 \S 52$ ff., about art. 7 Conv., Kokkinakis c. Grecia, May 25, 1993 § 40; Cantoni c. Francia, November 15, $1996 \S 28$ ff.; Achour c. Francia, March 29, $2006 \S 49$ ff.; Pessino c. Francia, October $10,2006 \S 28$.

12 J. Waldron, Judges Judges as Moral Reasoners, "International Journal of Constitutional Law" 2009, Vol. 7(2).

${ }^{13}$ N. Bobbio, Teoria generale del diritto, Torino 1993, p. 52 ff. 
2. The verbal predicate "transfer" does not imply a faculty. The norm is not formulated as if the transfer were a mere faculty of the simple sections: it is not written "can transfer".

3. The prescriptive nature of the rule could also be inferred from the duty to provide reasons borne by the simple section where it believes not to share the rule of law laid down by the Plenary Session: duty which resembles the similar duty of the $a$ quo judge which intends to raise a question of constitutional legitimacy by deferring the case to the Constitutional Court.

4. The circumstance that no sanction is provided for the case where the simple session decides not to transfer the case to the Plenary Session and issues an autonomous opinion is not conclusive in denying the prescriptive nature of Article 99. Rules of structure (such as those that regulate the functioning of an institution) are rarely accompanied by a sanction but are nevertheless binding ${ }^{14}$.

5. Finally, pursuant to Articles 74 and 88 of the Italian Administrative Procedure Code, the judge may fulfill his duty to give reasons by simply referring to a precedent (which shall obviously be on the same issue). According to our reasoning, such a precedent shall be the rule laid down by the Plenary Session.

6. The framework above described could not be easily reduced to the nomofilactic function of the Plenary Session.

\section{THE ACTUALITY OF DEBATE}

The awareness of the existence of a binding precedent emerges from the Consiglio di Giustizia Amministrativa per la Regione Sicilia (Council of Administrative Justice for the Region of Sicily) decision of 26 September $2013^{15}$ with which the Italian administrative Judge made a request for a preliminary ruling to the EU Court of Justice concerning the trial rules which must be followed for analysing a cross-claim and the principles of effectiveness and the primacy of EU law.

The main question is ascertaining whether Article $267 \mathrm{TFEU}$ is to be interpreted as precluding a provision of national law, in so far as that provision is interpreted to the effect that, where a question concerning the interpretation or validity of EU law arises, a chamber of a court of final instance must, if it does not concur with the position adopted by decision of that court sitting in plenary session, refer the question to the plenary session and is thus precluded from itself making a request to the Court of Justice for a preliminary ruling.

Article 99 of the Italian Administrative Procedure Code provides as follows:

${ }^{14}$ Ibidem, p. 58.

15 See: www.giustizia-amministrativa.it [access: 10.02.2018]. 
1. Where the Chamber to which the appeal is assigned considers that the point of law submitted for its consideration has given rise, or might give rise, to divergences in judicial decisions, it may, by order made on application by one of the parties or of its own motion, refer the case to be heard by the court in plenary session. The plenary session may, if it deems appropriate, refer the matter back to the Chamber.

2. Before a decision is delivered, the President of the Consiglio di Stato (Council of State) may, on application by one of the parties or of his own motion, refer any appeal to the court in plenary session for a ruling on questions of principle of particular importance or with a view to resolving divergences in judicial decisions.

3. If the Chamber to which the appeal is assigned does not concur with a principle of law stated by the plenary session, it shall, by reasoned order, refer the decision on the appeal to the plenary session [...].

In the light of the Article 99 the Italian Judge has asked:

In the event that doubts arise as to whether a principle of law already stated by the Consiglio di Stato (Council of State) in plenary session is in conformity with or is compatible with EU law, is the Chamber or Division of the Consiglio di Stato (Council of State) to which the case is assigned under an obligation to make a reasoned order referring the decision on the appeal back to the plenary session, even before it is able to make a request to the Court of Justice for a preliminary ruling as to whether the principle of law in question is in conformity with or is compatible with EU law; or, instead, may - or, rather, must - the Chamber or Division of the Consiglio di Stato (Council of State), being a national court against whose decisions no appeal lies, independently refer - as an ordinary court applying EU law - a question to the Court of Justice for a preliminary ruling so as to obtain the correct interpretation of EU law?

It is not a case that the bond of precedent is intended to cede only where the relative applications end up to elude the Community law: principle stated by the $\mathrm{CJEU}^{16}$ whose judgment confirms the theoretical system of the binding precedent for future decisions. Indeed, even though the lien would not be binding on a domestic level, would have not sense the Community Judge statement that broke the case raised by the Italian Administrative Judge when referral was requested concerning the possibility that the direct application of EU law and in particular the Article 267 TFEU crashes with the Article $99 \S 3$ of the Administrative Procedure Code.

The debate shows all his actuality as the scholars ${ }^{17}$ and administrative decisions prove $^{18}$. The strength of binding precedent is intended to outline the trial rules in the administrative sector so long that Article $99 \S 3$ of the Administrative Procedure Code stretch out a common law model, focused on the stare decisis rule.

${ }^{16}$ EUCJ (Grand Chamber), April 5, 2016, C-689/13.

17 R. Rordorf, Nomofilachia e precedente giudiziario: Il precedente nella giurisprudenza, "Il Foro italiano" 2017, n. 1, p. 277; A. Proto Pisani, Tre note sui «precedenti» nella evoluzione della giurisprudenza della Corte costituzionale, nella giurisprudenza di una Corte di cassazione necessariamente ristrutturata e nella interpretazione delle norme processuali, "Il Foro italiano" 2017, n. 9, p. 295; G. Pesce, L'Adunanza plenaria del Consiglio di Stato e il vincolo del precedente, Napoli 2012.

${ }_{18}$ With decision of the Section IV No. 3805/2017 the State Council has asked to the Plenary Session to affirm whether, and in what extent, the principles from it enunciated can apply the "au- 


\section{CONCLUSIONS}

By acknowledging the doctrine of the stare decisis within our administrative justice some theoretical and legal puzzles shall be addressed ${ }^{19}$. Some have mainly a logical nature and as such predominantly tickle legal theorists: if judges are free to create law, why should the subsequent judge be bound by a precedent? In which occasions (and upon which circumstances) is the judge free in a way similar to the legislator, and when on the contrary is he bound?

Legal puzzles aren't easier. The Italian system of the sources of law is usually deemed to be closed and structured according to hierarchical and competence criteria.

And what about the rule of law? The rule of law, as set forth under Article 101 of the Italian Constitution (the judge is subject only to law) implies that a judge shall disregard a precedent which he deems contrary to law: for he has a duty to obey the law and not his colleague (including the Supreme Court of Cassation and the Plenary Session of the State Council) who laid down the rule of precedent. The contradiction, however, is more apparent than real. The judge who creates new law does not act in a vacuum but within a framework of standards and rules ${ }^{20}$. As a result, the binding precedent is fully consistent with the rule of law and the principle of legality ${ }^{21}$.

To follow J. Waldron the concept of the rule of law shall be captured under a layered approach: so that a judge sets forth a rule within a more general statutory framework and a subsequent judge continues in the work of defining the general rule to tailor it to specific empirical circumstances and so on.

As a last point. The analysis is confined to the administrative justice and as a result the dangerous specter of a powerful creator judge shall be dispelled: such a specter either comes under the appearance of the counter-majoritarian difficulty (where there is the suspicions that democracy is in danger) or under the much darker cloths of the inquisitor judge. The administrative justice, however, is much different than the criminal justice: if, as is often the case, the discretionary power of the judge is used in favor of the private citizen, the risk denounced by Beccaria and Montesquieu is averted.

thority of a final decision", and, therefore, in what measure with reference to said principle, can apply once the hypothesis of "revision" that the same resulted "not applied" from the Section, that has not prepared the delay instead to the senses of the Article 99, § 3, of the Administrative Procedure Code. Finally, the Plenary Session of State Council No. 2/2018 declare that from Article $99 \S 3$ of Italian Administrative Procedure born a "binding precedent".

19 G. Pesce, op. cit.

${ }^{20}$ S. Cassese, I Tribunali di Babele (I giudici alla ricerca di un nuovo ordine globale), Roma 2009, pp. $103 \mathrm{ff}$.

${ }^{21}$ J. Waldron, Stare decisis and the Rule of Law: A Layered Approach, [in:] Public Law \& Legal theory research paper sciences, NYU School of Law, October 2011. 
The system where the precedent is binding is not necessary that system where the judiciary power is omnipotent. The precedent is the Janus faced, which on the one hand raises the judge to the level of the legislator, on the other however binds him to his own decisions. It is, therefore, a mechanism which, rather than fostering individualistic attitudes, imposes forms of institutional cooperation and therefore of natural modesty.

\section{REFERENCES}

Achour c. Francia, March 29, 2006.

Bobbio N., Teoria generale del diritto, Torino 1993.

Cantoni c. Francia, November 15, 1996.

Cardozo B.N., Selected Writings of Benjamin Cardozo (Il giudice e il diritto), New York, 1947 (trad. it. Firenze, La Nuova Italia 1961).

Cassese S., I Tribunali di Babele (I giudici alla ricerca di un nuovo ordine globale), Roma 2009.

Cassese S., Problemi delle ideologie dei giudici, [in:] Studi in memoria di Carlo Esposito, Padova 1972.

Court of Justice of the European Union, October 6, 1982, causa C-283/81, Cilfit srl e Lanificio di Gavardo spa c. Ministero della Sanità, in Racc., 1982, 3415.

Court of Justice of the European Union, September 15, 2005, causa C-495/03, Intermodal Transports BV c. Staatssecretaris van Financiën, Racc., 2005, I-8151.

David R., I grandi sistemi giuridici contemporanei (a cura di Sacco), Padova 1973.

EUCJ (Grand Chamber), April 5, 2016, C-689/13.

Ferrari V., L'equivoco del giudice legislatore, 2017.

Guastini R., Il giudice e la legge, Torino 1995.

Kokkinakis c. Grecia, May 25, 1993.

Kopp c. Svizzera, March 25, 1998.

Kruslin c. Francia, April 24, 1990.

Lamond G., Precedent and analogy in legal reasoning, [in:] Stanford Encyclopedia of Philosophy, 2006, http://plato.stanford.edu/archives/sum2006/entries/legal-reas-prec [access: 10.02.2018].

Nigro M., Giustizia amministrativa, Bologna 1983.

Olivecrona K., Il diritto come fatto, Milano 1967.

Olivecrona K., Law as Fact, London 1939.

Patroni Griffi F., La sentenza amministrativa, [in:] Trattato di diritto amministrativo, a cura di S. Cassese, tomo V, Milano 2003.

Pesce G., L'Adunanza plenaria del Consiglio di Stato e il vincolo del precedente, Napoli 2012.

Pessino c. Francia, October 10, 2006.

Pound R., An Introduction to the Philosophy of Law, New Haven 1922.

Pound R., The deviation of American Law from English Law, "Law Quarterly Review" 1952, Vol. 67.

Proto Pisani A., Tre note sui «precedenti» nella evoluzione della giurisprudenza della Corte costituzionale, nella giurisprudenza di una Corte di cassazione necessariamente ristrutturata e nella interpretazione delle norme processuali, "Il Foro italiano" 2017, n. 9.

Rordorf R., Nomofilachia e precedente giudiziario: Il precedente nella giurisprudenza, "Il Foro italiano" 2017, n. 1.

Ross A., On Law and Justice (Diritto e giustizia), Torino 1965.

Sunday Times c. Regno Unito, decision April 29, 1979.

Tarello G., Storia della cultura giuridica moderna, Bologna 1976.

Valenzuela Contreras c. Spagna, July 30, 1999. 
Pobrane z czasopisma Studia Iuridica Lublinensia http://studiaiuridica.umes.pl

Data: 26/04/2023 11:36:35

176

Giovanni Pesce

Waldron J., Judges as Moral Reasoners, "International Journal of Constitutional Law” 2009, Vol. 7(2). Waldron J., Stare decisis and the Rule of Law: A Layered Approach, [in:] Public Law \& Legal theory research paper sciences, NYU School of Law, October 2011.

www.giustizia-amministrativa.it [access: 10.02.2018].

\section{STRESZCZENIE}

Artykuł obejmuje problematykę kompetencji włoskiej Rady Stanu (Consiglio di Stato) w świetle postanowień art. 99 kodeksu postępowania administracyjnego. Rada Stanu jest organem konsultacyjnym prawno-administracyjnym i zapewnia legalność administracji publicznej. Uznawana jest za bastion rządów prawa. Wobec powyższego autor zadaje pytania dotyczące przekształcenia wymiaru sprawiedliwości w sprawach administracyjnych w kierunku procesu common law. Konkluzja: sądownictwo administracyjne wykorzystuje swoje kompetencje w kierunku ochrony i korzyści obywatela. Mechanizm polegający na wykorzystaniu praktyki precedensowej, mający swoje podstawy w art. 99 kodeksu postępowania administracyjnego, narzuca formy współpracy instytucjonalnej w sądownictwie administracyjnym. Autor uważa, że wiążący precedens jest w pełni zgodny z zasadą praworządności i legalności.

Słowa kluczowe: Rada Stanu; precedens; postępowanie administracyjne 